Sudinadji M. B., \& Kumaidi K. (2019). Pengalaman self regulated learning siswa untuk menghadapi ujian. Indigenous: Jurnal Ilmiah Psikologi, 4(2), 79-95. https://doi.org/10.23917/indigenous.v4i2. 7970

\title{
Pengalaman Self Regulated Learning Siswa untuk Menghadapi Ujian
}

\author{
Muh Bagus Sudinadji ${ }^{1}$, Kumaidi Kumaidi ${ }^{2}$
}

Fakultas Psikologi, Universitas Muhammadiyah Surakarta ${ }^{12}$

bagus_sudinadji@ums.ac.id'1, Kumaidi@ums.ac.id²

\begin{abstract}
The completeness of a program in the education unit (in this case secondary school) will end with the holding of an evaluation of learning outcomes or exams, which are school exams and national exams, students will increase their learning activities in preparation for being able to take exams and try to produce satisfying achievements. This study aims to explain students' experiences in practicing self-regulated learning (SRL), which includes students' readiness in an active, constructive process, able to set learning goals, monitor, regulate, and control cognition, motivation, and behavior. This study uses a qualitative approach with data collection methods in the form of a focused group discussion (FGD) and essay writing on seven main informant students, plus interviews with seven supporting informants (subject friends). The informants in this study are students of class XII who have taken the school exams and national exams. The results of this study explain that the experience of SRL in students, in behavior, motivation, and cognitive (learning strategies), still requires an increase in the problem of time management, planning, and targets. Internally, the suitability of SRL is motivated by habits, motivation, and goals, while externally influenced by culture, parenting, and the environment. SRL is a managerial skill in learning because it regulates learning resources so that they can be taught or trained as early as possible to optimize academic skills and academic adjustment of students in the future.
\end{abstract}

Keywords : exam; self-regulated learning; student

Abstrak. Ketuntasan suatu program pada satuan pendidikan (dalam hal ini sekolah menengah) akan diakhiri dengan diselenggarakannya evaluasi hasil belajar atau ujian, yaitu ujian sekolah dan ujian nasional, siswa akan meningkatkan aktivitas belajarnya sebagai persiapan diri untuk dapat mengikuti ujian dan berusaha untuk menghasilkan prestasi yang memuaskan. Penelitian ini bertujuan untuk menjelaskan pengalaman siswa dalam mempraktekkan self-regulated learning (SRL), yang meliputi kesiapan siswa dalam proses yang aktif, konstruktif, mampu menetapkan tujuan belajar, memonitor, mengatur, dan mengontrol kognisi, motivasi, serta perilaku. Penelitian ini menggunakan pendekatan kualitatif dengan metode pengumpulan data berupa focused group discussion (FGD) dan tulisan karangan pada tujuh siswa informan utama, ditambah dengan wawancara pada tujuh informan pendukung (sahabat subyek). Informan dalam penelitian ini adalah siswa kelas XII yang sudah menjalani ujian sekolah dan ujian nasional. Hasil penelitian ini menjelaskan bahwa pengalaman SRL pada siswa, secara perilaku, motivasi, dan kognitif(strategi belajar), masih memerlukan peningkatan pada masalah pengaturan waktu, perencanaan, serta target. Secara internal, kesesuaian SRL dilatarbelakangi oleh kebiasaan, motivasi, dan tujuan, sedangkan secara eksternal dipengaruhi oleh budaya, pola asuh, dan lingkungan. SRL merupakan ketrampilan manajerial dalam belajar karena mengatur sumberdaya belajar sehingga dapat diajarkan atau dilatihkan sedini mungkin untuk mengoptimalkan ketrampilan akademis dan penyesuaian akademis siswa di waktu yang akan datang.

Kata kunci: self-regulated learning; siswa; ujian. 


\section{PENDAHULUAN}

Kesiapan dalam menghadapi ujian akan ditunjukkan oleh tindakan siswa dalam mengelola sumber daya baik dari dalam dirinya, dari lingkungannya dan dari bahanbahan belajar yang ada. Peluang memperoleh keberhasilan pada ujian di sekolah berkaitan dengan apakah siswa telah melakukan persiapan yang memadai sebelumnya. Keterlibatan siswa dalam mendorong mutu akademis dirinya pada masa-masa sebelum ujian tiba (ujian sekolah dan ujian nasional) merupakan proses yang sangat erat dengan makna penting kelulusan. Persiapan sebelum menjalani ujian merupakan momen yang berharga, belajar sebagai "aktivitas" dan belajar sebagai "hasil" adalah hal produktif yang akan membantu siswa dalam menjalani ujian. Tahap yang berkaitan dengan menyiapkan pembelajar (siswa) untuk belajar adalah langkah penting, tanpa ini pembelajaran menjadi lambat dan bisa berhenti (Meier, 2002).

Peneliti melakukan dua tahap penelitian preliminari di lapangan yaitu pada guru dan siswa. Pada guru Bimbingan Konseling di beberapa sekolah menengah atas dan kejuruan, peneliti memperoleh informasi mengenai permasalahan yang umumnya terjadi di beberapa bulan atau minggu sebelum ujian akhir dijalani: (1) hasil evaluasi belajar siswa tidak bermasalah tetapi sikap/minat pada belajar masih rendah, (2) perasaan percaya diri yang positif untuk menghadapi ujian tetapi tanpa dibarengi persiapan (belajar) yang serius, (3) perasaan negatif dalam bentuk kecemasan, kejenuhan, kebingungan, momok, gelisah, khawatir, dan sebagainya (4) kurang memiliki prioritas pada aktivitas sehari-hari yang mengarah pada persiapan (kurang proaktif), (5) cara-cara belajar yang kurang optimal (kebingungan mengolah/ mengatur materi), (6) siswa enggan/keberatan mencari variasi materi/soal di luar sekolah, (7) siswa mengalami gangguan kesehatan atau psikosomatis (stres), (8) perasaan yang dituntut untuk fokus pada usaha-usaha dalam mempelajari materi disertai kecemasan untuk menguasai materi pelajaran, (9) pemaknaan negatif terhadap ujian sebagai "problem" dari lingkungannya, pengaruh orangtua/keluarga, pengaruh sekolah/guru, pengaruh rekan/kakak kelas, pengaruh masyarakat dan pengaruh media massa yang biasanya memberitakan kasus yang menimbulkan kecemasan terhadap ujian, atau karena kurangnya kematangan siswa dalam menilai ujian sebagai siklus yang wajar sehingga mempengaruhi kualitas persepsi siswa sendiri terhadap ujian. Peneliti menyimpulkan bahwa, data di atas pada umumnya menunjukkan pada adanya permasalahan dalam kemampuan atau keterampilan siswa untuk mengelola aktivitas belajar, sumber belajar, lingkungan belajar dan mengelola atau mengatur diri dalam masa persiapan sebelum ujian. Pada kalangan siswa, peneliti melakukan identifikasi kepada 50 siswa Kelas XII tentang "Apa yang akan dilakukan untuk memperbaiki dan meningkatkan kemampuan Anda pada mata pelajaran yang akan diujikan, sehingga kelulusan nanti dapat

Tabel 1. Variasi Jawaban Siswa Tentang "Apa yang akan dilakukan untuk dapat memperbaiki dan meningkatkan kemampuan Anda pada mata pelajaran yang akan diujikan?”

\begin{tabular}{|c|c|c|c|}
\hline Motivasional & Spiritual & Tindakan & Lain-lain \\
\hline Bekerja keras & Berdoa terus & $\begin{array}{l}\text { Banyak bertanya kepada teman } \\
\text { dan guru }\end{array}$ & $\begin{array}{l}\text { Saling } \\
\text { menolong }\end{array}$ \\
\hline Belajar sungguh-sungguh & Berdoa kepada Allah & $\begin{array}{l}\text { Menekuni mapel yang kurang } \\
\text { dikuasai }\end{array}$ & $\begin{array}{l}\text { Membantu } \\
\text { orangtua }\end{array}$ \\
\hline Berfikir positif & Banyak ibadah & Memperbanyak latihan soal & \\
\hline Berusaha maksimal & $\begin{array}{l}\text { Mendekatkan diri pada } \\
\text { Allah }\end{array}$ & Berusaha menyenangi belajar & \\
\hline \multirow[t]{2}{*}{ Berusaha menjadi lebih baik } & Perbanyak doa dan ibadah & Memperbaiki belajarnya & \\
\hline & & $\begin{array}{l}\text { Menghidari hal-hal yang membuat } \\
\text { tidak fokus belajar }\end{array}$ & \\
\hline
\end{tabular}


memuaskan?" Setelah mengelompokkan jawaban dari responden, maka didapatkan empat kategori jawaban yang bersifat motivasional, spiritual, tindakan, dan Lain-lain (Tabel 1).

Peneliti menyimpulkan bahwa jawaban Motivasional dan Spiritual menunjukkan kondisi sikap normatif, sebagai tekad yang pada umumnya akan dilakukan oleh semua orang ketika menghadapi permasalahan. Keinginan sukses yang dimunculkan dalam bentuk katakata tekad atau motivasi, dan doa atau ibadah untuk mendapat "dukungan spiritual" dari Allah SWT dapat mengkondisikan individu menjadi lebih tenang dan bersemangat. Demikian pula ketika memberikan perhatian kepada orang lain (pada jawaban lain-lain) sebagai bentuk timbal balik bahwa dirinya membutuhkan dukungan sosial dalam menghadapi ujian dan menjalani persiapan ujian.

Sementara pada kategori jawaban Perilaku mengindikasikan keadaan siswa yang menyadari adanya permasalahan pada pencapaian belajarnya saat itu, mengetahui kualitas progres belajarnya, memiliki target tertentu, atau telah memiliki pemikiran untuk mengatasi secara sistematis dan melakukan upaya nyata dalam menyelesaikan masalah belajarnya. Hal ini mengundang ketertarikan peneliti untuk meninjau lebih dalam bagaimana pengalaman siswa dalam menjalani belajar sebagai persiapan untuk ujian yang akan dijalaninya. Siswa yang mengetahui atau menyadari bagaimana upaya dan cara-cara yang baik dalam belajar, maka siswa tersebut akan melakukan secara kongkrit apa yang perlu dikerjakannya. Siswa tersebut akan mampu mengembangkan ketrampilan belajar dan mengembangkan kemandirian dalam belajar. Kemampuan pemantauan diri, evaluasi diri dan instrospeksi terus menerus pada siswa adalah karakteristik kunci yang harus dimiliki pembelajar, siswa harus mengetahui dan mengenal kekuatan serta kelemahannya sehingga dapat mengambil tindakan yang tepat (Rose \& Nicholl, 2002).

Penelitian ini terkait dengan caracara belajar yang "bertujuan", sebagai upaya siswa untuk mencapai optimalisasi dalam menghadapi ujian, sehingga dapat mencapai kelulusan. Derek Rowntree (dalam Rose \& Nicholl, 2002) berpendapat bahwa jika individu "terjun" ke dalam belajar tanpa sebelumnya mempertimbangkan tujuan, terdapat kemungkinan terjadinya waktu yang terbuang atau upaya yang sia-sia. Upaya untuk mengarahkan siswa yang akan mengikuti ujian telah dilakukan oleh pihak sekolah. Upaya itu berupa penyelenggaraan program pendalaman materi pelajaran secara terjadual di sekolah, yang biasanya dikenal dengan istilah "pemadatan".

Program ini bertujuan untuk memperbaiki, meningkatkan dan menjaga kualitas hasil belajar siswa. Permasalahan yang muncul selanjutnya adalah ketersediaan waktu dan kesempatan yang tidak mencukupi untuk penyampaian seluruh materi secara runtut, beresiko timbulnya pembelajaran yang "dipaksakan". Oleh karena itu, siswa perlu memiliki kemampuan dalam mengantisipasi dan mengatur keadaan.

Sebagaimana pandangan dari Meier (2002) bahwa karena terlalu "bernafsu" untuk merampungkan materi maka seringkali tahap mempersiapkan siswa menjadi terabaikan. Belajar bukan merupakan suatu peristiwa yang pendek, belajar terjadi secara bergelombang, sehingga memerlukan beberapa ekspose materi untuk mencerna dan memahaminya, lebih penting lagi adalah cara bagaimana ekspose itu terjadi (Silberman, 2001).

Pada siswa-siswa yang memiliki dan menggunakan cara-cara "ekspose", mampu belajar dengan baik, memiliki ketrampilan belajar sehingga dapat mengatur atau mengelola proses belajar sesuai kebutuhannya. Pengaturan proses belajar dikenal dengan sebutan Self Regulated Learning disingkat SRL atau Pengaturan Diri dalam Belajar (yang selanjutnya akan disebut dengan SRL). Apabila siswa memiliki keterlibatan komprehensif melalui pengaturan diri dalam proses belajarnya, maka siswa dapat memasuki the ideal condition of learning sehingga optimal dalam mempersiapkan diri menghadapi ujian nasional.

Individu yang memiliki SRL dapat menggunakan masa persiapannya secara efektif. Individu dengan SRL menunjukkan pencapaian 
Tabel 2. Cakupan Tema pada Tiap Kategori

\begin{tabular}{llll}
\hline Perilaku & Motivasi & Kognisi & Dinamika menghadapi ujian \\
\hline $\begin{array}{l}\text { Kontrol waktu belajar } \\
\text { secara umum dan mulai } \\
\text { persiapan untuk ujian }\end{array}$ & Orientasi belajar & Strategi belajar & Kecemasan \\
Kontrol lingkungan tempat & Sumber motivasi & $\begin{array}{l}\text { Pengembangan } \\
\text { metakognitif }\end{array}$ & kebutuhan rasa tenang/nyaman \\
Kontrol lingkungan sosial & Kontrol emosi & & \\
\hline
\end{tabular}

yang lebih positif pada hasil akademiknya daripada individu yang tidak terbiasa berperilaku dengan SRL (Barnard-Brak, Lan, \& Paton, 2010). SRL terdiri dari tiga fase yang dilalui individu, yaitu a) berpikir dan merencanakan masa depan, b) melaksanakan dan memanta unya, serta c) merefleksi hasil yang dilakukannya (Farber, 2012).

Beberapa penelitian terdahulu telah menjelaskan tentang cara siswa mengatur diri dalam belajar dalam kaitannya dengan hal yang ingin dicapai. Fink (Wirth \& Perkins, 2013) dalam penelitiannya menyampaikan bahwa program pendalaman materi di masa persiapan menghadapi ujian nasional atau secara umum membantu evaluasi PBM setiap hari merupakan hal yang pantas dikritisi. Lebih lanjut, Fink menyatakan bahwa pengajaran instruksional dari guru tidak selalu berhasil, banyak siswa tidak mengalami "belajar", karena apa yang dipelajarinya tertahan.

Buku The Learning Guide yang diterbitkan oleh Cardiff Centre for Lifelong Learning (Cardiff Centre for Lifelong Learning, n.d.) dijelaskan bahwa buruknya mengelola waktu belajar mengakibatkan tidak mencapai deadline yang tersedia, pekerjaan yang dihasilkan tidak sesuai kemampuan yang terbaiknya, serta timbulnya perasaan gagal dan stres. Diperlukan strategi yang dapat menolong dan membuat individu mampu mengontrol atau mengatur waktu dan belajarnya. Menurut studi yang dipublikasikan oleh Organisation for Economic Co-operation and Development (OECD) pada tahun 2004 (OECD, 2004) jika seorang siswa merasa terasing dan terputus dari konteks belajar di sekolahnya, maka terdapat kemungkinan terjadinya penurunan ketrampilan dasar siswa, konsep-konsep dan pengembangan ketrampilan belajar efektif.

Sisswa-siswa yang lemah dalam belajar, membutuhkan bantuan agar menjadi efektif dan menjadi pembelajar yang mampu mengatur dirinya. SRL adalah proses yang dapat membantu siswa dalam mengelola proses berfikir, mengelola perilaku dan mengelola emosinya untuk memandu kesuksesan belajarnya (Zumbrunn, Tadlock, \& Roberts, 2011).

Masa persiapan adalah bagian penting dari proses kesiapan dalam menghadapi ujian. Kesiapan yang diiringi dengan kemampuan dan kecakapan siswa untuk mengatur dirinya (SRL) selama proses belajar merupakan tindakan organisasional yang konstruktif. Studi tentang SRL menjelang ujian merupakan masalah yang menarik untuk diketahui. Penelitian ini bertujuan untuk menjelaskan pengalaman siswa dalam mempraktekkan SRL, yang meliputi kesiapan siswa dalam proses yang aktif, konstruktif, mampu menetapkan tujuan belajar, memonitor, mengatur, dan mengontrol kognisi, motivasi, serta perilaku.

\section{METODE}

Penelitian ini merupakan studi kasus yang menggunakan metode kualitatif. Peneliti menggunakan dua kelompok informan, yaitu tujuh informan utama dan tujuh informan pendukung berasal dari SMKN Tengaran Kabupaten Semarang. Pemilihan informan penelitian ini menggunakan kriteria atau ciriciri adalah siswa di kelas XII yang mengikuti ujian sekolah dan ujian nasional 2014/2015. Metode pengumpulan data pada penelitian ini terdiri dari (1) Metode Focused Group Discussions, (2) Dokumen Tulisan Pengalaman, dan (3) Wawancara, sedangkan kebsahan data 
menggunakan triangulasi sumber-sumber data yang berbeda, peneliti membandingkan dan memeriksa data-data dari hasil FGD, Karangan dan hasil wawancara pada Sahabat informan. Kemudian dilakukan pemeriksaan hasil transkripsi untuk memastikan tidak adanya kesalahan-kesalahan yang dibuat selama proses transkripsi, dan penegasan tidak adanya definisi serta makna yang mengambang mengenai kode-kode selama coding. Adapun teknik analisis data dalam penelitian ini mengacu pada analisis data menurut Creswell (2009) sebagai berikut; (1) Mengolah dan mempersiapkan data, (2) Membaca keseluruhan data, (3) Menganalisis lebih detail dengan meng-coding data, (4) Menerapkan proses coding untuk mendeskripsikan setting, orang-orang, kategorikategori dan tema yang akan dianalisis, (5) Menunjukkan bagaimana deskripsi dan tematema ini akan disajikan kembali dalam narasi atau laporan kualitatif, dan (6) Interpretasi data.

\section{HASIL DAN PEMBAHASAN}

Kontrol penggunaan waktu belajar secara umum dan waktu memulai persiapan untuk ujian

Penggunaan waktu secara umum adalah aktifitas belajar siswa yang dilakukan rutin setiap harinya. Perbedaan ariasi waktu yang digunakan, baik itu karena siswa melakukan pengaturan secara jelas maupun pengaturan berdasarkan kondisi psikologis (mood) akan memberikan pencapaian peroses belajar yang lebih baik. Selain itu penggunaan waktu SRL dapat mandiri/perorangan maupun secara kelompok ketika mereka dengan teman-temannya menyepakati belajar bersama. Sejalan dengan penjelasan Britton dan Tesser (1991), perbedaan penggunaan waktu secara perorangan dalam penelitian ini menunjukkan bahwa waktu yang dimiliki siswa sesungguhnya terbatas dan pada umumnya pengelolaan waktu yang dimilikinya menggambarkan tentang perbedaan individual.

Ada tiga waktu yang menonjol digunakan oleh beberapa informan, yaitu BD, $\mathrm{MA}$, dan $\mathrm{MN}$ mengutamakan penggunaan waktu belajar setelah salat isya atau jam 19.00, sedangkan pada $\mathrm{AD}, \mathrm{BD}, \mathrm{MA}, \mathrm{MN}$ belajar di waktu dini hari atau pagi sebelum berangkat sekolah dilakukan. AS menambahkan pada sore dan BD memperbanyak waktu belajar saat libur. Penggunaan waktu belajar yang tidak menentu juga ditunjukkan oleh $\mathrm{AD}$, IW dan UF, karena menurutnya dengan mood maka belajar akan menjadi lebih baik.

Terkait dengan hal pengaturan waktu belajar untuk memulai persiapan menghadapi ujian di kelas XII, informan IW, MA, MN dan UF memperhatikan waktu sebagai aset untuk memulai belajar sedini mungkin, sedangkan BD memulai berlajar dengan terfokus pada awal kelas XII, UF mengalami kondisi yang kurang optimal meskipun sudah mulai belajar sedini mungkin sehingga pada semester I dan II di kelas XII dirinya merasa perlu lebih bekerja keras. Sementara untuk AD dan AS merasakan lebih optimal untuk belajar ketika ujian sudah dekat demikian pula BD. Ketiga informan ini memiliki tipe suka belajar pada detik-detik menjelang ujian berlangsung.

Pemahaman tentang SRL berkaitan dengan masalah manajemenwaktu(Zimmerman, 2002), manajemen waktu memainkan peran penting dalam meningkatkan prestasi akademis siswa (Nasrullah \& Khan, 2015). Setiap siswa harus memiliki kemampuan manajemen waktu yang mencakup penetapan tujuan dan prioritas, dengan menggunakan mekanisme manajemen untuk mengatur penggunaan waktu, dengan demikian kemampuan dalam mengelola waktu yang tepat akan menuntun siswa kapan belajar dan kapan tidak melakukannya, sehingga dalam hal ini akan menyentuh masalah kedisiplinan diri siswa. Kedisiplinan menurut Waitley dan Sasson (dalam Faruq, 2014) adalah identik dengan kontrol diri dan kemauan seseorang untuk melakukan suatu tindakan mencapai suatu tujuan tanpa harus teralihkan oleh kebiasan buruk atau menghindari dorongan yang mengakibatkan konsekuensi negatif.

Pengaturan waktu SRL bukan hanya dalam mengalokasikan kesempatan tertentu untuk belajar rutin tetapi juga terkait dengan perencanaan dan kesiapan siswa dalam menggunakan periode atau rentang waktu 
tertentu yang lebih panjang untuk mulai mengarahkan belajarnya sebagai usaha persiapan diri untuk menghadapi ujian. Jez dan Wassmer (2015) dalam studi dampak waktu belajar terhadap prestasi akademik menyebutkan bahwa penggunaan waktu belajar yang panjang berkaitan dengan peningkatan level kinerja akademik.

Perencanaan yang disusun akan meningkatkan kesiapan dalam menghadapi ujian. Kesiapan (readiness) adalah kapasitas (kemampuan potensial) baik bersifat fisik maupun mental untuk melakukan sesuatu (Uno, 2006). Kesiapan belajar bukan hanya, motorik, sosial-emosional, perilaku, kognitif tetapi juga ditunjukkan dengan keterampilan fisik dan bahasa (Millians, 2011). Apabila siswa merasa siap untuk ujian maka siswa akan menunjukkannya dengan perilaku belajar sehingga apa yang menjadi tujuan pembelajaran tercapai dengan baik. Menurut kamus psikologi (Chaplin, 2006), kesiapan mengandung dua pengertian yaitu: (a) keadaan siap siaga untuk mereaksi atau menanggapi, (b) tingkat perkembangan dari kematangan atau kedewasaan yang menguntungkan untuk mempraktekkan sesuatu.

\section{Kontrol lingkungan tempat}

$\mathrm{AD}$, AS, IW, MA, dan MN memperhatikan masalah kerapian untuk kenyamanan belajar. Selain AS dan MN, mereka juga suka mengubah kondisi tempat belajrnya agar tidak membosankan demikian juga BD dan UF. Dalam hal ketenangan suasana, MA sangat memperhatikan, berbeda sekali dengan AD yang justru dapat belajar dalam suasana yang "hidup" atau ramai (suara tv, orang ngobrol). Tentang kunjungan ke perpustakaan, AD, IW, MA, MN dan UF lebih menonjol daripada AS dan BD, bahkan pencarian bahan soal ke toko buku hanya dilakukan oleh $\mathrm{AD}$. AD juga lebih berminat menggunakan internet untuk mendapatkan bahan-bahan latihan daripada informan lainnya. Sementara AS punya inisiatif untuk ikut belajar/mendalami di kelas lain. Dari kesemua informan yang menyukai duduk terdepan saat pelajaran di kelas hanya dilakukan
$\mathrm{AD}$.

Menurut Corno, Winne, dan Zimmerman (dalam Sardareh, Saad, \& Boroomand, 2012), siswa dengan SRL akan merencanakan dan mengendalikan waktu dan usaha untuk dihabiskan dalam tugas, dan mereka tahu bagaimana menciptakan dan menyusun lingkungan yang menguntungkan, seperti menemukan tempat yang cocok untuk belajar dan mencari bantuan dari guru dan teman sekelas saat mereka menghadapi masalah.

Beberapa informan yang menyukai suasana kurang tenang, belajar di depan televisi, belajar di sekitar orang yang sedang mengobrol, menandakan kemampuan unik dalam berkonsentrasi terhadap materi yang dipelajarinya. Sementara informan yang lain hanya dapat belajar terfokus ketika suasana tenang. Untuk memahami keunikan kemampuan konsentrasi tersebut, Van Blerkom (2011) menegaskan bahwa ada perbedaan besar dalam kemampuan berkonsentrasi, karena dengan hanya menghilangkan gangguan eksternal saja tidak akan menjamin siswa dapat berfokus pada aktifitasnya, dijumpai beberapa siswa setelah mereka menghilangkan "suara" eksternal di sekitarnya, muncul "suara" internal yang lebih sering, konsekuensinya para siswa memerlukan kemampuan dalam meminimalisasi distraksi yang ada di dalam dirinya maupun di luar dirinya (Van Blerkom, 2011).

Beberapa siswa mencari bantuan kepada guru dan teman serta tetapi ada pula yang menggunakan internet. Penggunaan lingkungan akses internet untuk pencarian bantuan oleh informan didukung dengan hasil penelitian lain yang menunjukkan adanya korelasi positif antara pembelajaran berbasis internet dan pembelajaran tradisional (face to face) dengan SRL (Lee \& Tsai, 2011). Oleh karena itu fasilitas yang tersedia di sekolah dan dapat diakses akan meningkatkan proses pembelajaran siswa. Alat dan bahan yang tepat untuk perbedaan individu siswa dapat membantu siswa untuk merencanakan dan menerapkan teknik metode pengajaran yang tepat dan strategi untuk perbedaan individu, bahan pengajaran yang 
sesuai, tata letak kelas yang sesuai untuk para siswa, dan partisipasi aktif dalam proses belajarmengajar (Kubat, 2018).

Tinjauan pencarian informasi melalui internet terkait dengan konsep PLE (personal learning environment) yaitu pendekatan belajar yang berorientasi pada pelajar yang dapat mengatur sendiri lingkungan belajarnya (baik konten maupun proses belajar), berkolaborasi dan bertukar pengetahuan dengan orang lain, mengintegrasikan sistem belajar formal dan informal. Praktek PLE membutuhkan selfmotivation yang kuat dan kompetensi untuk mengelola lingkungan belajar, termasuk mencari dan menggunakan beragam tools dan layanan yang tersedia di internet (Putri, Laksitowening, \& Suwawi, 2015).

\section{Kontrol lingkungan sosial}

Kontrol lingkungan sosial adalah inisiatif siswa dalam memberdayakan orangorang di sekitarnya untuk mempermudah proses belajar yang sedang dilakukannya. Tema ini masih terkait dengan tema ke tujuh tentang strategi SRL yang dilakukan siswa dalam bentuk pencarian bantuan kepada guru, teman sekelas, teman antar kelas, atau teman antar sekolah. Kemampuan siswa mengatur lingkungan sosialnya akan memberikan kesempatan dalam memperoleh orang-orang yang tepat sebagai sumber belajar, dengan demikian siswa mendapatkan dukungan sosial yang memuaskan. Lavasani dan Khandan (2011) menjelaskan bahwa siswa menangani masalah belajar mereka melalui diskusi, konsultasi dan pencarian bantuan, memberikan solusi alternatif untuk menyelesaikan masalah dan mempelajari berbagai strategi pemecahan masalah dengan bantuan teman sekelas dan guru. Jenis pembelajaran inilah para siswa mengetahui bahwa mereka tidak dapat sepenuhnya berhasil sendiri dan membutuhkan bantuan orang lain untuk menyelesaikan masalah.

Akses ke guru untuk peningkatan penguasaan materi lebih menonjol dilakukan oleh AD, BD, IW, MA dan UF. Kesemua informan juga mengandalkan keterlibatan teman-teman sekelas sebagai sumber belajarnya karena umumnya memiliki kelompok belajar. BD, IW dan UF secara langsung memanfaatkan teman-temannya yang lebih pandai. Sementara MA menyukai untuk membandingkan bahan ujian yang dimilikinya ke teman kelas lain dan sekolah lain. Siswa memerlukan inisiatif untuk dapat memanfaatkan atau menciptakan lingkungannya sehingga membantu dalam peningkatan kualitas belajar. Hal ini sejalan dengan pendapat Reinders dan White (2011) bahwa lingkungan belajar yang baru memerlukan peran otonomi pembelajar. Aktifitas SRL dalam dimensi sosial yang ditunjukkan oleh responden sesuai dengan penjelasan Vygotsky (Murray, 2014) yaitu siswa dalam lingkungannya menunjukkan hubungan antara otonomi siswa, saling ketergantungan dan kolaborasi. Otonomi siswa atau pembelajar ditunjukkan dengan perilaku mencari bantuan (academic help seeking behavior), pencarian bantuan ini memiliki hubungan positif dengan peningkatan kompetensi akademik siswa (Payakachat et al., 2013). Hubungan sosial tersebut secara simultan menjadi dukungan sosial yang mempengaruhi informan menjalankan SRL dengan lebih baik. Dukungan sosial dari guru dan teman sebaya dapat berperan penting karena siswa belajar untuk lebih mengatur diri sendiri (Zumbrunn et al., 2011).

Salah satu fungsi guru dan teman adalah sebagai sumber belajar yang dapat memberikan umpan baik atas pencapaian yang telah diperoleh siswa tentang suatu mata pelajaran tertentu. Menurut Hamid, Nyeneng, dan Rosidin (2013) umpan balik (feedback) dalam aktifitas terkait pembelajaran merupakan kondisi yang menginformasikan kepastian kepada siswa bahwa kegiatan belajar telah atau belum mencapai tujuan, menunjukkan sejauhmana penguasaan siswa dalam menyelesaikan permasalahan.

\section{Orientasi belajar}

Belajar adalah kegiatan yang bertujuan dan belajar adalah aktifitas yang memiliki arah. Dalam penelitian ini, diperoleh serangkaian keterangan yang menggambarkan maksud dari aktifitas belajar yang informan lakukan dan 
Tabel 3. Kesesuaian Sub Tema Orientasi Hasil Penelitian dengan Tujuan tiap Orientasi dari Taylor

\begin{tabular}{|c|c|c|c|c|c|c|c|}
\hline \multirow[b]{2}{*}{$\begin{array}{c}\text { Orientasi Belajar } \\
\text { Taylor } \\
\text { Orientasi } \\
\text { Belajar Informan }\end{array}$} & \multicolumn{2}{|c|}{ Vokasional } & \multicolumn{2}{|c|}{ Akademik } & \multicolumn{2}{|c|}{ Personal } & \multirow{2}{*}{$\begin{array}{c}\text { Sosial } \\
\text { Kesem- } \\
\text { patan }\end{array}$} \\
\hline & Training & $\begin{array}{l}\text { Kualifi- } \\
\text { kasi }\end{array}$ & Minat & $\begin{array}{l}\text { Berpendi- } \\
\text { dikan }\end{array}$ & $\begin{array}{l}\text { Pengem- } \\
\text { bangan }\end{array}$ & $\begin{array}{l}\text { Kemam- } \\
\text { puan }\end{array}$ & \\
\hline $\begin{array}{c}\text { Self efficacy dan self } \\
\text { talk }\end{array}$ & + & + & + & + & + & + & \\
\hline $\begin{array}{c}\text { Pertanggungan } \\
\text { jawab }\end{array}$ & + & & + & + & + & + & \\
\hline $\begin{array}{c}\text { Perencanaan masa } \\
\text { depan }\end{array}$ & + & + & + & & + & + & \\
\hline $\begin{array}{c}\text { Menunjukkan diri } \\
\text { dan Pembuktian } \\
\text { diri }\end{array}$ & + & + & & & & + & \\
\hline Pencapaian target. & + & + & + & & + & + & \\
\hline
\end{tabular}

selanjutnya dikelompokkaan ke dalam tema orientasi belajar yang mencakup: Self efficacy dan self talk yang menggerakkan aktifitas belajar informan, belajar karena pertanggungan jawab, belajar karena bagian dari perencanakan masa depan, belajar untuk menunjukkan diri dan pembuktian diri, dan belajar dengan menetapkan target.

Dilihat dari respon informan pada penelitian ini dan mempertimbangkan jenis orientasi belajar tersebut, maka terdapat keterkaitan antara respon informan dengan tiga jenis orientasi yang pertama. Peneliti menyusun kesesuaian (tanda + ) dengan memasangkan orientasi dan tujuan belajar dari Taylor dan Brown (1988) dengan keterangan dari informan dalam Tabel 3.

Pencapaian tujuan belajar dan konsistensi aktifitas yang sesuai dengan orientasi belajar akan memerlukan dukungan motivasi pada diri siswa. Motivasi dapat dimiliki siswa melalui upaya-upaya tertentu, peneliti merujuk dan mengutip empat dari delapan hal terbentuknya motivasi dari buku "Orientation to College Learning” oleh Van Blerkom (2011) yaitu tentang hal-hal yang sebaiknya dilakukan agar dapat menumbuhkan motivasi: a) fokus pada tujuan, dengan tujuan maka akan meningkatkan motivasi yang memberi energi, mengarahkan, dan menopang perilaku menuju tujuan tertentu (misalnya lulus); b) percayalah bisa berhasil, perasaan bisa sukses (self efficacy) dapat memotivasi setiap hari untuk melakukan yang terbaik; c) menetapkan tujuan yang spesifik, dengan hal ini maka siswa akan lebih mudah termotivasi karena tahu secara persis apa yang perlu dilakukan, misalnya menetapkan tujuan belajar secara spesifik setiap hari, jangan hanya sekedar mengatakan "akan mengerjakan PR tetapi katakan, misalnya saya perlu "membaca halaman 22 sampai 42 buku Pendidikan Relijiusitas jam 7 malam”; d) biasakan self-talk yang positif, misalnya katakan "aku dapat melakukannya" setiap memulai sebuah tugas, katakan "tugas ini penting dan sebanding dengan usaha yang harus saya lakukan", dengan mengatakan hal positif tentang diri dan tentang tugas/materi belajar, akan membantu memotivasi dalam mengambil waktu dan usaha yang dibutuhkan untuk menyelesaikan tugas tersebut.

Self efficacy memiliki keterkaitan dengan SRL (Wolters, Yu, \& Pintrich, 1996; Zimmerman, 2002) demikian pula self talk (Pintrich, 2000); penelitian Wolter (dalam Schunk \& Zimmerman, 2012) menyimpulkan bahwa siswa yang menguasai self talk positif menunjukkan usaha dan ketekunan, menggunakan perencanaan (target) dan pemantauan strategi pembelajaran. Dengan demikian siswa yang memiliki self talk positif dan self efficacy menggambarkan sebagai pribadi yang bertanggungjawab dan berkeinginan untuk menunjukkan kemampuan dirinya (pembuktian).

Orientasi belajar yang mengarah sebagai bentuk pertanggungjawaban diri yang menunjukkan adanya pengembangan personal memunculkan konsekuensi pengaturan diri yang menyebar ke ranah lainnya, sebagaimana 
penelitian (Zhou dan Wang (2019) yang menyimpulkan bahwa tujuan orientasi memiliki korelasi positif dengan manajemen waktu/lingkungan belajar siswa dan strategi penyesuaian usaha-usahanya.

\section{Sumber motivasi}

Pembahasan motivasi dalam kaitannya dengan aktifitas belajar merupakan topik yang relevan karena berkaitan dengan pencapaian tujuan belajar. Menurut Wolters, motivasi adalah faktor penting selama semua fase pembelajaran: sambil merencanakan untuk belajar, selama belajar, serta setelah belajar ketika proses dan hasil belajar dievaluasi (Wolters, 2003).

Penjelasan pada sub sebelumnya, tentang perolehan motivasi pada siswa oleh Van Blerkom (2011) merupakan motivasi yang bersifat intrinsik (self efficacy, self talk, tujuan spesifik). Selanjutnya tentang sumber motivasi pada sub ini memiliki keterkaitan dengan motivasi ekstrinsik, peneliti memperhatikan bahwa dalam motivasi ekstrinsik informan dipengaruhi oleh hubungan sosial di sekitarnya, yaitu oleh orang-orang khusus yang memiliki kedekatan dengan informan atau karena statusnya sebagai keluarga atau teman belajar. Keluarga memengaruhi perilaku belajar anak dan prestasi akademik karena keluarga adalah lingkungan utama dan paling signifikan yang terpapar pada anak-anak (Li \& Qiu, 2018).

Seluruh informan menunjukkan peran pengabdian kepada orangtua sebagai motivasi utama dalam usaha belajar yang dilakukannya, adanya orang khusus seperti pacar dan "penciptaan" kompetisi bersama teman-temannya hanya dikemukakan oleh AS, faktor guru dan hadirnya teman-teman yang positif juga mempengaruhi motivasi MN. Zimmerman (dalam Zimmerman \& Schunk, 2011) menunjukkan bahwa berbagai penelitian telah mempelopori dukungan sosial pada SRL, penelitian berbagai macam dukungan sosial (misalnya: pemodelan, perancah, dan dukungan teman, guru, orang tua, dan saudara kandung), dimana presmis dari penelitian ini adalah: SRL adalah proses intrinsik, didukung dan dipengaruhi oleh interaksi sosial.
Pembahasan sumber motivasi (ekstrinsik) di atas memiliki keterkaitan dengan kemampuan individu dalam melakukan kontrol emosi, penggunaan strategi belajar dan pengelolaan sumber stres.

\section{Kontrol emosi}

Kontrol emosi adalah kemampuan siswa dalam stabilisasi perkembangan emosi yang menyertai dirinya dalam menghadapi beban, deadline, tuntutan, ketidakjelasan pemahaman, pengulangan yang menguras tenaga dan berbagai permasalahan dalam belajarnya. Kanfer, Ackerman, dan Heggestad (dalam Keith \& Frese, 2005) menerangkan bahwa kontrol emosi adalah keterampilan yang melibatkan penggunaan proses self regulatory untuk menjaga kecemasan kinerja dan reaksi emosional negatif lainnya (seperti: khawatir) selama pelaksanaan tugas. Pengendalian emosi diharapkan dan terbukti sangat penting pada proses belajar di tahap awal perolehan keterampilan, di mana biasanya mudah terjadi kesalahan dan kemunduran.

Cara mengatasi emosi yang negatif, $\mathrm{AD}$ memilih belajar secara bertahap sedikit demi sedikit. AD, AS dan UF juga berusaha membangun perasaan yang positif. Termasuk mengisi jeda belajar dengan kegiatan yang menyenangkan juga dilakukan oleh $\mathrm{AD}$ dan IW. Sementara BD dan MA berusaha mengambil hikmah ketika merasakan masalah, bahkan MA juga berusaha menyadari suasana dan peran dirinya serta berupaya menyukai mata pelajaran yang sedang dipelajarinya. Keputusan belajar sejak jauh hari, perasaan adanya dukungan guru serta lingkungan teman yang positif juga membantu kontrol emosi MN. Secara fisik, ketika emosi tidak menyenangkan, UF akan menggunakan pengolahan nafas. Suasana kompetitif bersama rekan belajarnya dapat membantu AS dalam mengatur emosi dan motivasinya menjadi lebih baik karena bersemangat.

Kanfer dan McCombs (dalam Zimmerman \& Schunk, 2001) menegaskan bahwa diperlukan dua kemampuan dasar self-regulatory selain juga strategi kognitif 


\section{Tabel 4. Keterkaitan aktifitas belajar yang dilakukan informan dengan strategi belajar dari} Effeney, Carroll, \& Bahr (2013)



dalam pengembangan self-regulation dan pemahaman peserta didik tentang peran diri dalam menangani proses pembelajaran: yaitu pengendalian motivasi dan pengendalian emosi. Mega, Ronconi, dan De Beni (2014) menegaskan pula bahwa emosi positif akan menumbuhkan prestasi akademik hanya ketika dimediasi oleh pembelajaran dan motivasi yang diatur siswa sendiri.

Pada penelitian ini, informan melakukan upaya untuk kontrol terhadap emosi yang muncul dengan cara belajar bertahap sedikit demi sedikit, membangun perasaan positif, mengisi jeda dengan kegiatan yang menyenangkan, curhat, menyadari suasana dan peran, mencari hikmah dari beban tugas, belajar jauh-jauh hari agar tidak panik, berusaha menyukai mata pelajaran yang diujikan, menenangkan diri dengan mengatur nafas (deep breath relaxation), mendapatkan dukungan guru, dan memiliki teman-teman yang positif.

\section{Strategi belajar}

Strategi SRL para siswa dipengaruhi oleh tingkat perkembangan perolehan ketrampilan siswa dalam menggunakan berbagai strategi. Faktor yang mempengaruhi perkembangan perolehan strategi SRL pada siswa adalah karena guru, orangtua dan lingkungan rumah, saudara kandung dan teman-teman sebaya, serta penemuan-penemuan teknis pada pengalaman pribadi (Effeney, Carroll, \& Bahr, 2013).

Tabel 4 adalah perbandingan kesesuaian ketrampilan belajar atau strategi belajar informan pada penelitian ini dengan berbagai strategi yang ditunjukkan dari hasil penelitian Effeney et al. (2013)

Penelitian ini memperoleh berbagai strategi belajar yang dilakukan siswa, yaitu: 
Pemanfaatan perpustakaan; Toko buku; Browsing soal online; Menjadi guru privat atau tutor sebaya bagi teman lainnya; Berdiskusi di kelas atau kelompok; Latihan soal; Mencari bantuan kepada teman yang tepat; Mencari bantuan pada guru yang tepat; Membandingkan hasil tryout; Cara membuat catatan khusus, menandai, kata kunci, bagan, simbol; ilustrasi; Meminjamkan catatan; dan Pendalaman di kelas lain, dengan teman beda kelas, atau teman beda sekolah. Strategi tersebut merupakan wujud ketrampilan siswa untuk memenuhi kebutuhan dan pencapaian materi serta hasil belajar yang diperlukan. Keterampilan belajar adalah istilah yang sangat luas yang digunakan untuk menggambarkan berbagai ketrampilan yang diperlukan untuk memperoleh keterampilan dan pengetahuan baru, khususnya dalam lingkungan formal di sekolah atau universitas (Higgins, Baumfield, \& Hall, 2007).

Strategi konsekuensi diri tidak ditemukan pada informan, kemungkinan informan tidak terbiasa membuat atau merencanakan pemberian ganjaran atau hukuman bagi keberhasilan atau kegagalannya. Peneliti masih mempertanyakan, apakah konsekuensi dengan memberikan hukuman atau ganjaran bagi diri sendiri dipengaruhi oleh lingkungan, pola asuh, budaya? Apakah lingkungan individu mengajarkan konsekuensi diri sehingga secara otonom (tanpa perlu orang lain yang melakukan) akan menghukum atau menghargai atas kesalahan atau kesuksesan yang diperbuat dirinya?

\section{Pengembangan metakognisi siswa}

Tenaga bidang psikologi di sekolah memiliki peran yang luas untuk pengembangan siswa yaitu: a) Memberikan konseling, pengajaran, dan pendampingan, meningkatkan prestasi dengan menilai hambatan belajar dan menentukan strategi instruksional terbaik untuk meningkatkan pembelajaran, b) mempromosikan kesehatan dan ketahanan dengan memperkuat komunikasi dan keterampilan sosial, pemecahan masalah, manajemen kemarahan, regulasi diri, penentuan nasib sendiri, dan optimisme, c) meningkatkan pemahaman dan penerimaan beragam budaya dan latar belakang (Windy, 2011).

Secara operasional di kelas, self regulated learning menjadi tanggung jawab tenaga bidang psikologi di sekolah untuk mempromosikan, melatihkan, mengevaluasi dan memperbaiki permasalahan kegiatan belajar siswa. Sehingga para tenaga di bidang kependidikan memerlukan bekal pengetahuan metakognitif (metacognitive knowledge) dan dapat menjelaskan pengalaman atau regulasi metakognitif (metacognitive experiences or regulation).

Metakognisi diperkenalkan oleh Flavell (1971): a) Pengetahuan metakognitif menunjuk pada diperolehnya pengetahuan tentang prosesproses kognitif, pengetahuan yang dapat dipakai untuk mengontrol proses kognitif. b) Sedangkan pengalaman metakognitif adalah proses-proses yang dapat diterapkan untuk mengontrol aktivitas-aktivitas kognitif dan mencapai tujuantujuan kognitif.

Livingston (1997) menyebutkan bahwa metakognitif sebagai thinkingabout thinking atau berpikir tentang berpikir atau proses berpikir yang terjadi pada diri sendiri, dan dalam Watkins (2001) beberapa ahli lainnya mengartikan metakognisi sebagai thinking about thinking, learning to think, learning to study, learning how to learn, learnig to learn, learning about learning. Sementara itu Matlin (1998) dalam bukunya Cognition, menyatakan : "Metacognition is our knowledge, awareness, and control of our cognitive process". Metakognisi, menurut Matlin, adalah pengetahuan, kesadaran, dan kontrol terhadap proses kognitif yang terjadi pada diri sendiri.

Hidayat, Zulnaidi, dan Syed Zamri (2018) menegaskan bahwa niat tujuan yang kuat tidak akan memastikan tujuan pencapaian karena siswa mungkin akan gagal menggunakan SRL selama pencapaian tujuan. Oleh karena itu, orientasi tujuan, yang merupakan fase dan subproses SRL, berperan untuk mengintegrasikan proses metakognitif (misalnya perencanaan dan penggunaan strategi) dan motif kognitif sosial. Metakognisi adalah strategi penting yang terhubung dengan hasil pembelajaran, banyak peneliti telah mengindikasikan bahwa orientasi tujuan terkait erat dengan metakognisi siswa. 


\section{Kegelisahan}

Keterangan informan yang dihimpun menunjukkan adanya kegelisahan siswa akibat tuntutan, sikap dan perlakuan guru dalam memotivasi, juga karena banyaknya bahan atau materi yang dipelajari dan masalah persiapan ataupun pelaksanaan ujian.

Sujit dkk. (dalam Hashmat, Hashmat, \& Amanullah, 2008) melaporkan bahwa kondisi kurangnya strategi belajar dalam hal ini gaya belajar yang tidak efektif, mempelajari konten materi yang tidak konsisten, melakukan aktifitas belajar sepanjang malam menjelang ujian, proses pembelajaran yang tidak efisien, termasuk kurangnya kajian dan atau kurang melakukan revisi materi pelajaran yang dipelajari adalah faktor utama yang menyebabkan kecemasan terkait ujian.

Informan $\mathrm{AD}$, $\mathrm{AS}$ dan $\mathrm{BD}$ mudah mengalami kegelisahan dengan tuntutan dan sikap guru tentang pencapaian prestasi dalam ujian yang akan dihadapi, $A D$ juga terpengaruh oleh kesiapan kuantitas bahan dan penguasaan materi. AD, AS, BD, IW dan UF mengalami kegelisahan dalam persiapan menghadapi ujian dan dalam pelaksanaannya.

\section{Kebutuhan rasa tenang dan nyaman}

Kebutuhan rasa tenang yang dialami siswa ditunjukkan dengan adanya informan yang baru dapat melakukan belajar berdasarkan mood, melakukan aktifitas ibadah (spiritual) salat tahajud dan dhuha, dan mencari hiburan (mendengarkan atau memainkan musik).

Mood memiliki pengaruh terhadap pemrosesan kognitif (Nadler, Rabi, \& Minda, 2010) bahwa mood yang positif memungkinkan peningkatan fleksibilitas kognitif, fleksibilitas yang meningkat ini terkait dengan korteks prefrontal dan korteks cingulate anterior, yang keduanya memainkan peran penting dalam pengujian hipotesis dan pemilihan aturan, dengan demikian, tugas kognitifyang bergantung pada perilaku seperti pengujian hipotesis dan pemilihan aturan dapat bermanfaat dari mood positif, sedangkan tugas yang tidak bergantung pada perilaku semacam itu seharusnya tidak terpengaruh oleh mood positif.

Pemenuhan kebutuhan rasa tenang dan nyaman melalui aktifitas ibadah yang meningkat dalam bentuk salat tahajjud dan doa memiliki relevansi dengan penelitian yang dilakukan Sayeed dan Prakash (2013) yang dilatarbelakangi oleh hasil studi tentang penerapan doa dalam psikoterapi memiliki hasil positif pada individu yang menunjukkan gejala patologis seperti ketegangan, kecemasan, depresi, dan kecenderungan anti-sosial. Studi-studi ini telah menyoroti kemanjuran salat sebagai obat untuk tekanan mental ketika dilakukan secara benar. Karena Salat adalah tindakan penyerahan diri kepada Allah, orang beriman menempatkan total imannya tanpa syarat kepada Tuhan dan memohon untuk menerima doa. Sementara itu Doufesh, Faisal, Lim, dan Ibrahim (2012) melakukan penelitian selama posisi sujud saat salat dhuha yaitu tingkat amplitudo alfa yang lebih tinggi dan aktifitas di daerah parietal dan oksipital dibandingkan dengan kondisi istirahat.

Temuan serupa dengan penelitian lain yang mendokumentasikan peningkatan amplitudo alfa di daerah parietal dan oksipital selama meditasi dan konsentrasi mental. Gejala peningkatan amplitudo alfa menunjukkan aktivasi parasimpatis, sehingga mengindikasikan keadaan relaksasi.

Pendekatan rohani yang dipraktekkan informan untuk memiliki ketenangan spiritual melalui aktifitas ibadah atau salat yang dilakukannya dalam persiapan menghadapi ujian termasuk sebagai aktifitas koping relijius (religious coping). Koping relijius memiliki kombinasi dalam bentuk: a) mencari makna religius atau spiritual yang dianggap berasal dari permasalahan yang menekan; b) Bimbingan tujuan; dan c) Penggunaan metode/pendekatan/ ritual keagamaan dalam mendapatkan tujuan (Pargament, Koenig, \& Perez, 2000). Banyak penelitian yang menunjukkan bahwa agama dapat menjadi kekuatan positif untuk kesehatan fisik dan mental (Utami, 2012).

Salah satu teori koping relijius dari Pargament (Xu, 2016) menjelaskan adanya lima fungsi utama koping relijius yaitu: untuk menemukan makna/hikmah, untuk 
mendapatkan kontrol, untuk mendapatkan kenyamanan karena perasaaan dekat dengan Tuhan, dan untuk mencapai kedekatan dengan orang lain serta untuk mengubah kehidupan. Berbagai penelitian telah banyak yang berfokus pada peran agama dalam mengatasi tekanan utama kehidupan. Studi empiris telah menunjukkan bahwa banyak orang memilih agama sebagai sumber daya dalam usaha mereka untuk memahami dan menghadapi masa-masa sulit dalam kehidupan (Pargament, Feuille, \& Burdzy, 2011).

Terkait dengan hal pemenuhan kebutuhan pada kenyamanan melalui musik, Meier (Yuliyani, 2011) mengatakan bahwa belajar dipengaruhi oleh perasaan, dan perasaaan dapat dipengaruhi oleh musik, apabila perasaan siswa positif dan siswa berada dalam kondisi santai dan terbuka, maka neokorteks (otak belajar) akan dapat terjangkau oleh proses pembelajaran. Sebaliknya apabila perasaan negatif dan siswa merasa tertekan maka akan cenderung turun ke otak reptil sehingga yang terjadi bukan tujuan untuk belajar tetapi untuk bertahan. Dengan demikian belajar akan melambat dan bisa berhenti.

Musik memiliki pengaruh yang unik pada jiwa manusia karena hubungannya dengan proses emosional. Ehlert, Mohiyeddini, Nater, Ryf, dan Thoma (Kwong, 2016) melakukan penelitian untuk mengeksplorasi hubungan antara musik dan persepsi emosional. Hasilnya menunjukkan bahwa ada korelasi yang kuat antara jenis emosi dan gaya musik yang disukai. Secara umum, gaya lagu mencerminkan jenis emosi di lingkungan yang dibayangkan, pendengar menghubungkan musik tertentu dengan emosi tertentu. Studi ini membuktikan, peserta memiliki kecenderungan untuk memilih musik yang terhubung dengan persepsi emosi yang sedang muncul, artinya otak menemukan cara untuk menghubungkan makna emosional dengan rangsangan pendengaran.

\section{SIMPULAN}

Ketujuh informan menunjukkan praktek SRL dalam menjalankan aktifitas belajarnya, namun belum sepenuhnya memadai dalam masalah manajemen waktu, perencanaan, target dan khususnya dalam penerapan konsekuensi diri (hukuman atau ganjaran) ketika gagal pelaksanaan atau pencapaian. Siswa secara alami menggunakan cara belajar yang dianggapnnya paling efektif dan biasa untuk mengatasi masalahnya. Faktor yang mempengaruhi perkembangan kemampuan SRL siswa adalah kebiasaan, motivasi, tujuan, dan pengaruh kebiasaan lingkungan. SRL merupakan kemampuan yang dapat diajarkan karena berisi ketrampilan "manajerial" untuk mengatur semua sumber yang terkait dengan proses pembelajaran. Pemberian pengetahuan dan latihan tentang variasi strategi dalam SRL dapat meningkatkan ketrampilan belajar informan yang sementara ini diperoleh berdasarkan hasil pengalaman sepanjang hidup, termasuk dari lingkungan dimana cara-cara dalam belajar ditemukan (dari teman, keluarga) atau diinstruksikan (dari guru).

\section{REFERENSI}

Barnard-Brak, L., Lan, W. Y., \& Paton, V. O. (2010). Profiles in Self-Regulated Learning in the Online Learning Environment. International Review of Research in Open and Distance Learning, 11(1), 61-80. Retrieved from https://files.eric.ed.gov/fulltext/EJ881578.pdf

Britton, B. K., \& Tesser, A. (1991). Effects of time-management practices on college grades. Journal of Educational Psychology, 83(3), 405-410. https://doi.org/10.1037/0022-0663.83.3.405

Cardiff Centre for Lifelong Learning. (n.d.). The Learning Guide. Retrieved from https://www. cardiff.ac.uk/_data/assets/pdf_file/0008/749492/The-learning-guide-for-Continuing-andProfessional-Development.pdf

Chaplin, J. P. (2006). Kamus psikologi. Jakarta: PT. Raja Grafindo Persada. 
Creswell, J. W. (2009). Research design: pendekatan kualitatif, kuantitatif, dan mixed. Yogyakarta: Pustaka Pelajar.

Doufesh, H., Faisal, T., Lim, K.-S., \& Ibrahim, F. (2012). EEG Spectral analysis on muslim prayers. Applied Psychophysiology and Biofeedback, 37(1), 11-18. https://doi.org/10.1007/s10484011-9170-1

Effeney, G., Carroll, A., \& Bahr, N. (2013). Self-regulated learning: Key strategies and their sources in a sample of adolescent males. Australian Journal of Educational \& Developmental Psychology, 13, 58-74. Retrieved from https://www.newcastle.edu.au/_data/assets/pdf_ file/0012/100245/V13_Effeney_Carroll_Bahr.pdf

Farber, S. (2012). Education review. Retrieved from http://www.edrev.info/reviews/rev1191.pdf

Faruq. (2014). Disiplin diri pada mahasiswa yang menyusun skripsi. Unpublished minor thesis. Universitas Muhammadiyah Surakarta.

Flavell, J. (1971). Theories of learning in educational psychology. Retrieved from https://www. demenzemedicinagenerale.net/images/mens-sana/Theories_of_Learning_in_Educational_ Psychology.pdf

Hamid, M. A., Nyeneng, I. D. P., \& Rosidin, U. (2013). Perbandingan penggunaan feedback pada lembar jawaban siswa terhadap penguasaan konsep fisika melalui pembelajaran kontekstual. Retrieved from https://media.neliti.com/media/publications/121699-ID-perbandinganpenggunaan-feedback-pada-le.pdf

Hashmat, S., Hashmat, M., \& Amanullah, F. (2008). Factors causing exam anxiety in medical students. Journal of the Pakistan Medical Association, 58(4), 167-170. Retrieved from https:// www.ncbi.nlm.nih.gov/pubmed/18655422

Hidayat, R., Zulnaidi, H., \& Syed Zamri, S. N. A. (2018). Roles of metacognition and achievement goals in mathematical modelling competency: A structural equation modelling analysis. PLOS ONE, 13(11), e0206211. https://doi.org/10.1371/journal.pone.0206211

Higgins, S. E., Baumfield, V. M., \& Hall, E. (2007). Learning skills and the development of learning capabilities. In research evidence in education library. London: EPPI-Centre, Social Science Research Unit, Institute of Education, University of London.

Jez, S. J., \& Wassmer, R. W. (2015). The Impact of learning time on academic achievement. Education and Urban Society, 47(3), 284-306. https://doi.org/10.1177/0013124513495275

Keith, N., \& Frese, M. (2005). Self-regulation in error management training: Emotion control and metacognition as mediators of performance effects. Journal of Applied Psychology, 90(4), 677-691. https://doi.org/10.1037/0021-9010.90.4.677

Kubat, U. (2018). Identifying the Individual differences among students during learning and teaching process by science teachers. International Journal of Research in Education and Science, 4(1), 30-68. https://doi.org/10.21890/ijres.369746

Kwong, M. (2016). The impact of music on emotion: comparing rap and meditative yoga music. Inquiries Journal/Student Pulse, 8(5). Retrieved from http://www.inquiriesjournal.com/ a?id=1402

Lavasani, M. G., \& Khandan, F. (2011). The effect of cooperative learning on mathematics anxiety and help seeking behavior. Procedia - Social and Behavioral Sciences, 15, 271-276. https://doi. org/10.1016/j.sbspro.2011.03.085 
Lee, S. W.-Y., \& Tsai, C.-C. (2011). Students' perceptions of collaboration, self-regulated learning, and information seeking in the context of Internet-based learning and traditional learning. Computers in Human Behavior, 27(2), 905-914. https://doi.org/10.1016/j.chb.2010.11.016

Li, Z., \& Qiu, Z. (2018). How does family background affect children's educational achievement? evidence from contemporary China. The Journal of Chinese Sociology, 5(13), 1-21. https:// doi.org/10.1186/s40711-018-0083-8

Livingston, J. A. (1997). Metacognition: An overview. Retrieved from https://www.researchgate. net/publication/234755498_Metacognition_An_Overview

Matlin, M. W. (1998). Cognition. Forth Worth: Harcourt Brace College Publishers.

Mega, C., Ronconi, L., \& De Beni, R. (2014). What makes a good student? How emotions, self-regulated learning, and motivation contribute to academic achievement. Journal of Educational Psychology, 106(1), 121-131. https://doi.org/10.1037/a0033546

Meier, D. (2002). The accelerated learning handbook. Bandung: Kaifa.

Millians, M. (2011). Learning readiness. In S. Goldstein \& J. A. Naglieri (Eds.), Encyclopedia of child behavior and development. https://doi.org/10.1007/978-0-387-79061-9_1631

Murray, G. (2014). The social dimensions of learner autonomy and self-regulated learning. Studies in Self-Access Learning Journal, 5(4), 320-341. Retrieved from https://sisaljournal.org/ archives/dec14/murray/

Nadler, R. T., Rabi, R., \& Minda, J. P. (2010). Better mood and better performance: learning ruledescribed categories is enhanced by positive mood. Psychological Science, 21(12), 1770-1776. https://doi.org/10.1177/0956797610387441

Nasrullah, S., \& Khan, M. S. (2015). The impact of time management on the students' academic achievements. journal of literature, Languages and Linguistics, 11, 66-71. Retrieved from https://iiste.org/Journals/index.php/JLLL/article/view/23538/23819

OECD. (2004). Student learning: Attitudes, engagement and strategies. In learning for tomorrow's world. First results from PISA 2003. https://doi.org/10.1787/9789264006416-4-en

Pargament, K. I., Feuille, M., \& Burdzy, D. (2011). The brief RCOPE: Current psychometric status of a short measure of religious coping. Religions, 2(1), 51-76. https://doi.org/10.3390/ rel2010051

Pargament, K. I., Koenig, H. G., \& Perez, L. M. (2000). The many methods of religious coping: Development and initial validation of the RCOPE. Journal of Clinical Psychology, 56(4), 519-543. https://doi.org/10.1002/(SICI)1097-4679(200004)56:4<519::AIDJCLP6]>3.3. $\mathrm{CO} ; 2-\mathrm{T}$

Payakachat, N., Gubbins, P. O., Ragland, D., Norman, S. E., Flowers, S. K., Stowe, C. D., ... \& Hastings, J. K. (2013). Academic help-seeking behavior among student pharmacists. American Journal of Pharmaceutical Education, 77(1). https://doi.org/10.5688/ajpe7717

Pintrich, P. R. (2000). The role of goal orientation in self-regulated learning. In Handbook of selfregulation (pp. 451-502). https://doi.org/10.1016/B978-012109890-2/50043-3

Putri, I., Laksitowening, K. A., \& Suwawi, D. D. J. (2015). Implementasi dan analisis konsep personal learning environment pada learning management system. Retrieved from https://docplayer. info/36694991-Implementasi-dan-analisis-konsep-personal-learning-environment-padalearning-management-system.html 
Reinders, H., \& White, C. (2011). Special issue commentary : Learner autonomy and new learning environments. Language Learning \& Technology, 15(3), 1-3. Retrieved from https://hdl. handle.net/10652/2497

Rose, C., \& Nicholl, M. J. (2002). Cara Belajar cepat Abad XXI. Bandung: Nuansa.

Sardareh, S. A., Saad, M. R. B. M., \& Boroomand, R. (2012). Self-Regulated Learning Strategies (SRLS) and academic achievement in pre-university EFL learners. California Linguistic Notes, 37(1), 1-34. Retrieved from https://www.researchgate.net/publication/261435907_SelfRegulated_Learning_Strategies_SRLS_and_academic_achievement_in_pre-university_ EFL_learners

Sayeed, S., \& Prakash, A. (2013). The Islamic prayer (Salah/Namaaz) and yoga togetherness in mental health. Indian Journal of Psychiatry, 55(6), 224-230. https://doi.org/10.4103/00195545.105537

Schunk, D. H., \& Zimmerman, B. J. (2012). Motivation and self-regulated learning: theory, research, and applications. New York: Routledge.

Silberman, M. (2001). Active learning: 101 strategi pembelajaran aktif. Yogyakarta: YAPPENDIS.

Taylor, S. E., \& Brown, J. D. (1988). Illusion and well-being: A social psychological perspective on mental health. Psychological Bulletin, 103(2), 193-210. https://doi.org/10.1037/00332909.103.2.193

Uno, H. B. (2006). Perencanaan pembelajaran. Jakarta: Bumi Aksara.

Utami, M. S. (2012). Religiusitas, koping religius, dan kesejahteraan subjektif. Jurnal Psikologi, 39(1), 46-66. https://doi.org/10.22146/jpsi.6966

Van Blerkom, D. L. (2011). College study skills: Becoming a strategic learner. Boston, MA: Wadsworth.

Watkins, C. (2001). Learning about Learning enhances Performance. In F. McNeil (Ed.). Research Matters series, 13, 1-16. London: University of London Institute of Education.

Windy, A. (2011). Psikologi pendidikan \& psikologi sekolah. Retrieved from http://10103awm. blogspot.com/2011/04/psikologi-pendidikan-psikologi-sekolah.html

Wirth, K. R., \& Perkins, D. (2013). Learning to learn. Retrieved from http://www.montana.edu/ rmaher/barrier_courses/Learning to Learn Wirth.pdf

Wolters, C. A. (2003). Regulation of motivation: evaluating an underemphasized aspect of selfregulated learning. Educational Psychologist, 38(4), 189-205. https://doi.org/10.1207/ S15326985EP3804_1

Wolters, C. A., Yu, S. L., \& Pintrich, P. R. (1996). The relation between goal orientation and students' motivational beliefs and self-regulated learning. Learning and Individual Differences, 8(3), 211-238. https://doi.org/10.1016/S1041-6080(96)90015-1

$\mathrm{Xu}, \mathrm{J}$. (2016). Pargament's Theory of Religious Coping: Implications for Spiritually Sensitive Social Work Practice. British Journal of Social Work, 46(5), 1394-1410. https://doi.org/10.1093/ bjsw/bcv080

Yuliyani, W. (2011). Pemanfaatan musik dalam proses belajarmengajar. Retrieved from//witriyuliyani. blogspot.com/2011/06/pemanfaatan-musik-dalam-proses-belajar.html

Zhou, Y., \& Wang, J. (2019). Goal orientation, learning strategies, and academic performance in adult distance learning. Social Behavior and Personality: An International Journal, 47(7), 
1-20. https://doi.org/10.2224/sbp.8195

Zimmerman, B. J. (2002). Becoming a Self-Regulated Learner: An Overview. Theory Into Practice, 41(2), 64-70. https://doi.org/10.1207/s15430421tip4102_2

Zimmerman, B. J., \& Schunk, D. H. (2001). Self-Regulated Learning and Academic Achievement: Theoretical Perspectives. New York: Routledge.

Zimmerman, B. J., \& Schunk, D. H. (2011). Self-regulated learning and performance: An introduction and an overview. Educational psychology handbook series. Handbook of selfregulation of learning and performance (pp. 1-12). Routledge/Taylor \& Francis Group. 